\title{
SEPTATE UTERUS WITH CERVICAL DUPLICATION AND LONGITUDINAL VAGINAL SEPTUM
}

\author{
Sergio Conti Ribeiro ${ }^{1}$, Lucas Yugo Shiguehara Yamakami ${ }^{*}$, Renata Assef Tormena ${ }^{3}$, Walter da Silva Pinheiro ${ }^{4}$, Jose Alcione Macedo de Almeida ${ }^{5}$, Edmund Chada Baracat ${ }^{6}$
}

Study conducted at Gynecology Division, Hospital das Clínicas da Faculdade de Medicina da Universidade de São Paulo, São Paulo, SP

\author{
*Conrespondence: \\ Rua Joaquim Floriano, 466 conj. 708 \\ São Paulo - SP \\ CEP: 04534-002 \\ Tel/Fax: (11) 3079-5050 \\ sergiocontiribeiro@terra.com.br
}

\begin{abstract}
SUMMARY
We present the case of a 19-year-old nulligravida woman with severe dysmenorrhea since menarche; she was found to have a longitudinal vaginal septum, cervical duplication and two endometrial cavities, separated by a complete septum. Diagnosis and management of this unusual Müllerian anomaly are discussed in the context of a literature review.
\end{abstract}

KEY WORDS: congenital abnormalities. Uterine cervical diseases. Vaginal diseases. Uterus. Mullerian ducts.

\section{INTRODUCTION}

The description of Müllerian anomalies has greatly improved understanding of genital embryology. Since the description by McBean and Brumsted ${ }^{1}$ of a woman who had a septate uterus with cervical duplication and longitudinal vaginal septum, the number of reports of similar cases has increased considerably and challenged the classical theory of Müllerian development. The unidirectional caudal to cephalic fusion of the Müllerian ducts is incompatible with the presence of two cervices and a single unified uterine fundus, and reinforces the alternative bidirectional theory. ${ }^{2}$ We report the case of a woman with this rare anomaly. Our observations are discussed in the light of available literature concerning diagnosis and management of similar cases.

\section{Case report}

A 19-year-old nulligravida presented with severe dysmenorrhea since menarche at 12 years of age. She complained of cyclic urinary and intestinal pain. One year before, she was attended by a general practitioner who had prescribed an oral contraceptive and non-steroidal anti-inflammatory but had not diagnosed any genital anomaly. Although the pain had improved, she came to our institution for a second opinion. She had regular menses with normal menstrual bleeding; she denied difficulty initiating intercourse but complained of deep dyspareunia since her first sexual relations six years earlier.

Physical examination revealed a longitudinal vaginal septum beginning at the inferior third of the vagina and extending to the cervix. The longitudinal septum was attached to the medial anterior portion of the double cervix. There was no difficulty performing manual examination. Transvaginal ultrasound demonstrated a normal uterine contour and two endometrial cavities separated by a complete septum. Diagnosis was confirmed by magnetic resonance imaging, which revealed a single uterus with two endometrial cavities and two cervices associated with the vaginal septum. There were no abnormalities in the urinary tract.

The patient was taken to the operating room for a procedure involving both endoscopic and vaginal surgical approaches. The vaginal septum was resected, and the two cervices were unified using a monopolar electrode to avoid excessive bleeding. The uterine septum was then resected through hysteroscopy. Laparoscopy showed a normal uterine fundus without indentation and a $5 \mathrm{~mm}$ focus of endometriosis in the cul-de-sac was excised.

The patient's postoperative recovery was uneventful, and she was discharged from hospital the day after surgery. We prescribed conjugated estrogen for 21 days and medroxyprogesterone acetate for the last 10 days of this course. After the hormone therapy, the patient had normal menstrual bleeding with mild pain. Thereafter, cyclic combined oral contraceptive pills were started. Hysteroscopy performed two months postoperatively revealed a normal uterine cavity.

\section{Discussion}

Septate uterus with cervical duplication and a longitudinal vaginal septum is a rare congenital malformation. Since it was first described in $1994,{ }^{1}$ published reports suggest that the true incidence of the anomaly is more common than initially believed ${ }^{3}$.

1. Doutor em Medicina pela Faculdade de Medicina da Universidade de São Paulo - USP e Chefe do Setor de Laparoscopia da Disciplina de Ginecologia, São Paulo, SP

2. Médico Assistente da Disciplina de Ginecologia da Faculdade de Medicina da Universidade de São Paulo - FMUSP, São Paulo, SP

3. Médica Assistente da Disciplina de Ginecologia da Faculdade de Medicina da Universidade de São Paulo - FMUSP, São Paulo, SP

4. Doutor em Medicina pela Faculdade de Medicina da Universidade de São Paulo - FMUSP e Chefe do Setor de Histeroscopia e Coordenador Administrativo da Clínica Ginecológica, São Paulo, SP

5. Pós-doutorado em Medicina pela Faculdade de Medicina da Universidade de São Paulo - FMUSP e Chefe do Setor de Ginecologia da Infância e Adolescência, São Paulo, SP

6. Professor titular da Disciplina de Ginecologia da Faculdade de Medicina da Universidade de São Paulo - FMUSP, São Paulo, SP 
Patton et al. reported 16 patients with cervical duplication and a longitudinal uterine and vaginal septum; none had been diagnosed correctly before referral ${ }^{4}$. The most common misdiagnosis (10 cases) was didelphys uterus.

The unique characteristic of this malformation, a cervical duplication in the middle of a unified vagina and uterus, even in the presence of a complete septum, indicates clearly that it initiated during development in the middle portion of Müllerian ducts and extended cranially and caudally, as proposed by Musset et al. in 1967. ${ }^{2}$ Location of fusion initiation may vary among individuals, and this variability could explain the wide variety of uterine malformations observed.

Patients described in literature have presented with a variety of symptoms, including severe dysmenorrhea and infertility; some have been asymptomatic ${ }^{3-15}$ (Table 1). Interestingly, the great majority of patients, such as the present one, did not have difficulty with initiation of intercourse. Diagnosis is made by careful examination, followed by imaging. Magnetic resonance provides good cervical imaging and is the best noninvasive method for differentiating septate, bicornuate and didelphys uterus ${ }^{3,10,16}$. Most physicians, however, still use a combined approach with hysteroscopy and laparoscopy to confirm diagnosis.

The best approach to management which should provide relief of symptoms and preserve reproductive ability is controversial (Table 1). Resection of the vaginal septum is easy and commonly performed. Hysteroscopic resection of a uterine septum using a minimally invasive approach (improving obstetric outcomes) is the gold standard according to most authorities ${ }^{4,8}$.

There have been different methods reported to distend or indent the septum for the hysteroscopic incision, including use

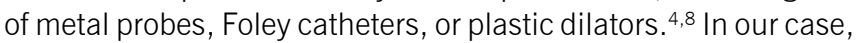
as we also unified a double cervix, we used this as a point of reference in the beginning of the uterine cavity to extend the resection with a monopolar electrode. The union of the two cervices is another area of controversy. Some authors believe that cervical manipulation increases risk of cervical incompetence and that there is a risk of problematic bleeding during surgery ${ }^{4,8}$. Others

Table 1 - Reported cases of septate uterus with cervical duplication and longitudinal vaginal septum

\begin{tabular}{|c|c|c|c|c|c|c|c|}
\hline Authors & $\mathbf{N}$ & Main symptom(s) & Imaging exams & $\begin{array}{l}\text { Resection of vaginal } \\
\text { septum }\end{array}$ & $\begin{array}{l}\text { Resection of uterine } \\
\text { septum }\end{array}$ & Cervix unified & Outcome \\
\hline McBean et al.1 & 1 & Metrorrhagia & US & No & No & No & $?$ \\
\hline Ergün et al. 6 & 1 & $\begin{array}{l}\text { Spontaneous abortion, } \\
\text { dysmenorrhea and } \\
\text { dyspareunia }\end{array}$ & US, HSG, IVP & Yes & Hysteroscopic & Yes & Pregnancy and cerclage \\
\hline Sharara et al.7 & 1 & Infertility & MRI, US, HSG & $?$ & $?$ & $?$ & $?$ \\
\hline Giraldo et al.8 & 1 & Infertility & HSG, MRI & Yes & Hysteroscopic & No & $?$ \\
\hline Wai et al. 9 & 1 & No symptoms & MRI, IVP, H, L & Yes & Tompkins & No & $?$ \\
\hline Hundley et al.10 & 1 & $\begin{array}{l}\text { Pelvic pain and } \\
\text { dyspareunia }\end{array}$ & MRI & Yes & No & No & $?$ \\
\hline $\begin{array}{l}\text { Saygili-Yilmaz et } \\
\text { al.11 }\end{array}$ & 9 & $\begin{array}{l}\text { Infertility, dyspareunia } \\
\text { and dysmenorrhea }\end{array}$ & HSG, IVP, H, L & $?$ & $?$ & $?$ & $?$ \\
\hline Pavone et al.12 & 1 & Infertility & MRI & Yes & No & No & Spontaneous pregnancy \\
\hline Hur et al.13 & 1 & $\begin{array}{c}\text { Malodorous vaginal } \\
\text { discharge }\end{array}$ & US, MRI, IVP & Yes & No & No & $?$ \\
\hline Badalotti et al.14 & 1 & Dysmenorrhea & US & No & No & No & Spontaneous pregnancy \\
\hline
\end{tabular}


RIBEIRO SC ET AL.

prefer to unify the cervices to facilitate surgery and decrease the likelihood of recurrent symptoms ${ }^{6,15}$. In patients with a complete uterine septum extending into the cervix, Parsanezhad et al. demonstrated that resection of the cervical septum made the hysteroscopic metroplasty easier, faster, and safer than preserving $i^{17}{ }^{17}$. In addition, this procedure did not increase the risk of cervical incompetence.

\section{Conclusion}

The presence of this unusual anomaly provides information relevant for our understanding of embryology. Because of the rarity of this condition, there is not yet sufficient evidence to establish consensus regarding management. Resection of the vaginal septum is easily performed; hysteroscopic resection of uterine septum requires more experience and is generally indicated, particularly in women with poor reproductive outcomes. The union of the two cervices remains controversial.

\section{Conflict of interest: none}

\section{Resumo}

\section{Útero SEPTADO COM DUPLICIDADE CERVICAL E SEPTO VAGINAL LONGITUDINAL}

No presente artigo, relata-se o caso de uma mulher de 19 anos com queixa de dismenorreia intensa desde a menarca. Diagnosticouse a presença de septo longitudinal vaginal, duplicidade cervical e duas cavidades endometriais, separadas por um septo completo. O diagnóstico e o manejo desta rara malformação Mülleriana são discutidos junto a uma revisão bibliográfica. [Rev Assoc Med Bras 2010; 56(2): 254-6]

Unitermos: Anormalidades congênitas. Doenças do colo do útero. Doenças vaginais. Doenças uterinas. Ductos paramesonéfricos.
3. Chang AS, Siegel CL, Moley KH, Ratts VS, Odem RR. Septate uterus with cervical duplication and longitudinal vaginal septum: a report of five new cases. Fertil Steril. 2004;81(4):1133-6.

4. Patton PE, Novy MJ, Lee DM, Hickok LR. The diagnosis and reproductive outcome after surgical treatment of the complete septate uterus, duplicated cervix and vaginal septum. Am J Obstet Gynecol. 2004;190(6):1669-75.

5. Balasch J, Moreno E, Martinez-Román S, Moliní JL, Torné A, Sánchez-Martín $F$, et al. Septate uterus with cervical duplication and longitudinal vaginal septum: a report of three new cases. Eur J Obstet Gynecol Reprod Biol. $1996 ; 65(2): 241-3$

6. Ergün A, Pabuccu R, Atay V, Kücük T, Duru NK, Güngör S. Three sisters with septate uteri: another reference to bidirectional theory. Hum Reprod. 1997;12(1):140-2

7. Sharara FI. Complete uterine septum with cervical duplication, Iongitudinal vaginal septum and duplication of a renal collecting system. A case report. J Reprod Med. 1998;43(12):1055-9.

8. Giraldo JL, Habana A, Duleba AJ, Dokras A. Septate uterus associated with cervical duplication and vaginal septum. J Am Assoc Gynecol Laparosc. 2000;7(2):277-9.

9. Wai CY, Zekam N, Sanz LE. Septate uterus with double cervix and longitudinal vaginal septum. A case report. J Reprod Med. 2001;46(6):613-7.

10. Hundley AF, Fielding JR, Hoyte L. Double cervix and vagina with septate uterus: an uncommon müllerian malformation. Obstet Gynecol. 2001;98(5 Pt 2):982-5.

11. Saygili-Yilmaz ES, Erman-Akar M, Bayar D, Yuksel B, Yilmaz Z. Septate uterus with a double cervix and longitudinal vaginal septum. J Reprod Med. 2004;49(10):833-6

12. Pavone ME, King JA, Vlahos N. Septate uterus with cervical duplication and a longitudinal vaginal septum: a müllerian anomaly without a classification. Fertil Steril. 2006;85(2):494.e9-10.

13. Hur JY, Shin JH, Lee JK, Oh MJ, Saw HS, Park YK, et al. Septate uterus with double cervices, unilaterally obstructed vaginal septum, and ipsilateral renal agenesis: a rare combination of müllerian and wolffian anomalies complicated by severe endometriosis in an adolescent. J Minim Invasive Gynecol. 2007;14(1):128-31.

14. Badalotti M, Arent A, Monteggia V, Machado J, Petracco R, Petracco A. Septo uterino, duplicação cervical e septo vaginal: relato de rara malformação mülleriana com gestação a termo. Rev Bras Ginecol Obstet. 2007;29(11):588-92.

15. Caliskan E, Cakiroglu Y, Turkoz E, Corakci A. Leiomyoma on the septum of a septate uterus with double cervix and vaginal septum: a challenge to manage. Fertil Steril. 2008;89(2):456.e3-7.

16. Ribeiro SC, Tormena RA, Peterson TV, Gonzáles Mde O, Serrano PG, Almeida JA, Baracat EC. Müllerian duct anomalies: review of current management. São Paulo Med J. 2009;127(2):92-6.

17. Parsanezhad ME, Alborzi S, Zarei A, Dehbashi S, Shirazi LG, Rajaeefard A, et al. Hysteroscopic metroplasty of the complete uterine septum, duplicate cervix, and vaginal septum. Fertil Steril. 2006(5);85:1473-7.

\section{REFERENCES}

1. McBean J, Brumsted JR. Septate uterus with cervical duplication: a rare malformation. Fertil Steril. 1994;62(2):415-7.

2. Musset R, Muller P, Netter A, Solal R, Vinourd JC, Gillet JY. Etat du haut appareil urinaire chez les porteuses de malformations uterines. Etude de 133 observations. Presse Med. 1967;75(26):1227-32.

Artigo recebido: 19/7/09 Aceito para publicação: 11/11/09 